Виктория ГРУКАЧ *

Олеся ТКАЧЕНКО

Татьяна СОЛОВЙОВА

\title{
ПРОЦЕСС ЛИШЕНИЯ ШЛЯХЕТСКИХ ПРАВ В КИЕВСКОМ ГЕНЕРАЛ-ГУБЕРНАТОРСТВЕ ВО 2 ЧЕТВЕРТИ ХІХ В.: НОВЫЕ ПАРАДИГМЫ И СОЦИАЛЬНЫЕ ТРАНСФОРМАЦИИ
}

\author{
THE PROCESS OF DESTROYING THE SZLACHTA'S PRIVILEGES IN THE \\ KYIV GENERAL GOVERNMENT IN THE SECOND QUARTER OF THE 19TH \\ CENTURY: NEW PARADIGMS AND SOCIAL TRANSFORMATIONS
}

\begin{abstract}
Based on documents preserved in the Central State Historical Archives of Ukraine (Kyiv), this paper details the process of integration and assimilation of the Polish gentry of Right-Bank Ukraine into the socio-political system of the Russian Empire. The authors further analyse the policies of the Kyiv general governors on depriving Poles of their noble rights during the second quarter of the $19^{\text {th }}$ century.
\end{abstract}

Keywords: Kyiv, governor-general, gentry, Szlachta, Poland, Ukraine

Актуальность исследования этносоциальных трансформаций на правобережных украинских землях, процесса лишения шляхетских прав в Киевском генерал-губернаторстве в XIX в. в современных условиях вызвана необходимостью понимания сложных и неоднозначных процессов в различных сферах жизни современного украинского общества, которые были порождены еще раньше, когда Российская империя активно проводила в украинских губерниях, в частности в правобережных, политику русификации и инкорпорации. Исследование социального развития данного региона

\footnotetext{
*ДВНЗ «Переяслав-Хмельницький ДПУ», Переяслав-Хмельницький,Україна; viktorijaghrukach@gmail.com.

*ДВНЗ «Переяслав-Хмельницький ДПУ», Переяслав-Хмельницький,Україна; Lesya612@ukr.net.

*ДВНЗ «Переяслав-Хмельницький ДПУ», Переяслав-Хмельницький,Україна; Soloveva071@ukr.net.
}

Analele Universităţii „Dunărea de Jos” din Galaţi, Seria 19, Istorie, tom XVIII, 2019, pp. 5-15. 
является важным, поскольку от него зависит стабильность и напряжение общества, его развитие, консолидация активной социально-политической, экономической и культурной жизни. Оно вызвано также необходимостью реформирования системы современного государственного управления, организации эффективной исполнительной власти в Украине на всех уровнях.

Первые попытки проанализировать некоторые аспекты генералгубернаторского правления было сделано в имперской историографии 2 половины XIX - начала XX в. Это труды: И. Андриевского, Е. Анучина, И. Блинова, О. Градовского, В. Шульгина та др. Отдельные аспекты деятельности института генерал-губернаторства в Российской империи, процесс лишения шляхетских прав в Киевском генерал-губернаторстве рассматривали и украинские историки XIX ст.: М. Грушевский, М. Драгоманов, М. Костомаров. Среди последних исследований интерес вызывают работы: М. Бармака, В.О. Грукач, С. Лисенко, А. Черепанова, Н. Щербак, В. Шандры, А. Филинюка, О. Ярмыш и др.

В конце XVIII в. после разделов Польши к Российской империи были присоединены правобережные украинские земли, где проживали украинцы, поляки, евреи и другие этносы. Там продолжало действовать польсколитовское законодательство, а власть в органах местного управления принадлежала польским магнатам и шляхте, которые владели основным богатством края - землёй. Своё право на владение правобережными украинскими землями российское правительство закрепило манифестом Екатерины II от 27 марта 1793 г., в котором были сформулированы задачи самодержавной власти в Правобережной Украине. ${ }^{1}$

Ликвидация Польского государства изменила статус польского населения Правобережья. На территории Правобережной Украины, вошедшей в состав Российской империи, царское правительство на законодательном уровне стремилось провести форсированную интеграцию поляков в политическую систему государства. После разделов Речи Посполитой все сословия польского общества были ущемлены в своих правах. Они были вынуждены, почувствовав давление государственного аппарата бюрократической монархии, которая не признавала основ сословной

\footnotetext{
${ }^{1}$ Полное собрание законов Российской Империи Собрание первое. (далі - ПСЗРИ-1) : с 1790 г. по 1795 г. СПб. .. Тип. II Отд-ния. Собствен. Канщелярии Его Императорского Величества) / Полное собрание законов Российской Империи 1796. с.102.
} 
шляхетской демократии, приспосабливаться к новым реалиям. Особых своих прав и многих привилегий лишалась категория шляхты. Ей была предоставлена возможность выбора - принести присягу на верность России и этим сохранить своё крупное землевладение, или же продать поместья и уехать за границу.

Чтобы инкорпорировать в состав империи территории Правобережной Украины, необходимо было наделить созданные местные российские учреждения государственной власти особыми полномочиями. Таким органом верховной власти и стал правовой институт генерал-губернаторства. Создание института Киевского генерал-губернаторства было обусловлено особенностями развития этого края: продолжением действия польсколитовского законодательства, наличием многоэтнического состава населения, отсутствием поддержки новой власти со стороны местной элиты, доминирующих католической и униатской церквей, дефицитом местных чиновников, лояльных к верховной власти. Правовое положение генералгубернаторов определял «Указ губернаторам» 1837 г., «Общая инструкция генерал-губернаторам» от 29 мая 1853 г., другие законодательные акты. ${ }^{2}$

Киевское генерал-губернаторство в системе властных структур Российской империи занимало особое место. Оно было образцом агрессивной деятельности генерал-губернаторов в отношении местной польской элиты, которая не хотела сотрудничать с российской самодержавной властью, а стремилась к возрождению своей государственности не только в польских, но и в украинских землях.

$\mathrm{B}$ начале XIX в. в Киевской губернии проживало подавляющее большинство польских дворян, что отразилось на составе дворянских учреждений. Общее количество российского дворянства вместе с безпоместными российскими чиновниками в 1812 г. составляло лишь около 1170 человек, тогда как польских шляхтичей насчитывалось более 43677 человек, из которых около 3 тыс. были помещиками, остальные представителями мелкой шляхты. ${ }^{3}$ Анализ законодательства начала XIX в. свидетельствует о намерениях правительства Александра I совместить установление контроля над политической жизнью присоединённых от Польши территорий с лояльностью к богатой польской шляхте, в которой оно видело свою опору в этом крае.

\footnotetext{
${ }^{2}$ ПСЗРИ - 2 : за 1837 г. СПб., 1838 ; ПСЗРИ-2 : за 1853 г. СПб., 1854. с.

${ }^{3}$ Соловйова T.М., Черепанов А.І. Київська губернія в першій половині XIX cm. : історико-правові , соціокультурні виміри. Переяслав-Хмельницький: ФОП Домбровська, 2017. с.120.
} 
После подавления польского восстания 1830-1831 гг., которое резко изменило отношение Санкт-Петербурга к присоединённым Западным губерниям, Правобережная Украина стала ареной острого противостояния польского и российского влияния, исторического опыта и традиций государственной жизни. Российско-польское противостояние в украинском регионе, который нами исследуется, наблюдалось в течение всего XIX и начала XX вв. Основным объектом административных, экономических и политических репрессий стала польская шляхта, участники восстания.

С введением Киевского генерал-губернаторства в составе трёх правобережных украинских губерний (Киевская, Волынская, Подольская) с 24 февраля 1832 г., в процессе реализации наступательной русификаторской политики, начался процесс декласации мелкой шляхты, лишение её сословных прав и привилегий. В процессе этого шляхтичи были вынуждены активно искать и предъявлять письменные доказательства своего благородного происхождения и привилегий. Такую политику царское правительство проводило в течение длительного времени и это привело к желаемым для власти результатам.

Согласно закону от 19 октября 1831 г. предусматривались различные меры по разделению польской шляхты в западных губерниях империи. В упомянутом законодательном акте подчёркивалось, что «...последние события...в возвращённых от Польши губерниях доказывали, что люди эти, из-за нехватки оседлости и собственности и по образу жизни многих из них, наиболее склонны были к восстанию ипреступным действиям против законной власти». ${ }^{4}$

Чтобы исправить ситуацию в крае, закон устанавливал, что за «действительными» шляхтичами, которые уже доказали свои дворянские права (шляхетство) в установленном порядке и были признаны Герольдией, сохранялись все права и привилегии российского дворянства. Остальная шляхта, не сумевшая письменными доказательствами подтвердить своё дворянство, разделялась на два разряда (в зависимости от места проживания): сельских и городских обывателей. Сельские жители получили название однодворцев той губернии, куда они должны быть приписаны. Второй разряд составляли шляхтичи, которые проживали в городах. Они получили название - граждан. Однодворцы в свою очередь делились на оседлых (которые владели землёй, жили с чиншу или с оброку на казенных или же на помещичьих землях) и неоседлых (таких, что проживали в доме помещика или у частных лиц в качестве прислуги). Тем лицам из граждан, которые занимались врачебной,

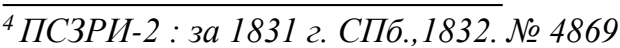


учительской, адвокатской практикой и т.п., было присвоено звание почётных граждан.

21 декабря 1831 г. Сенат известил Киевского военного губернатора Б.Княжнина о принципах организации ревизий, которые были предложены министром финансов Канкриным. Исходя из них, все шляхетские титулы должны были рассматриваться уездными комиссиями, в состав которых входили государственные чиновники, секретари и предводители местного дворянства. Полиция должна была следить за тем, чтобы в течение года с момента оглашения обращения вся шляхта прошла комиссию.

Впоследствии министр юстиции Дашков известил киевского генералгубернатора о том, что Николай I разрешил шляхте западных губерний (для упрощения процедуры ревизий) подавать бумаги в подтверждение своих прав сразу в Герольдию. Все лица из бывшей шляхты под их новыми названиями однодворцев и граждан должны быть занесены в посемейные списки, им разрешался переход из одного поселения в другое, но только с согласия казенных палат. Неоседлые люди и такие, которые ещё не были отнесены ни к одной из определённых категорий, должны были явиться для приписки в свои губернии или же приписаться в одну из указанных категорий там, где находились на момент выдачи указа. Для оформления приписки отводился годовой срок после того, как был опубликован указ. Все, кто не приписался в отведённый срок, считались бродягами, в отношении которых применялись уже другие меры воздействия. ${ }^{5}$

В результате «разделения» были определены повинности и подати для бывшей шляхты. Все приписанные однодворцы и граждане подлежали исполнению земельных повинностей, обязательной военной службе. Закон определял порядок отбывания ними воинской повинности. Почётные же граждане вместо несения лично военной службы обкладывались особым денежным сбором. Все другие категории бывшей шляхты исполняли военную службу лично, срок которой составлял 15 лет.

В судебном отношении однодворцы и граждане попадали под юрисдикцию городских магистратов или уездных судов исходя из прописки и места проживания. Впоследствии по поводу вопросов, возникших при исполнении указа от 19 октября 1831 г. был издан указ о разделе бывшей польской шляхты на три разряда. В первый разряд входила шляхта, которая была утверждена в дворянстве и обладала поместьями, крепостными или

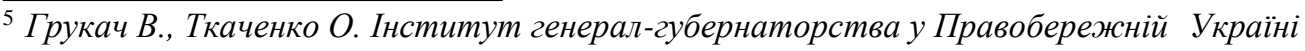
: правові засади та особливості функиіонування (1832-1914 рр.) ПереяславХмельнищький: ФОП Домбровська, 2017. с.56.
} 
дворовыми людьми. Второй разряд составляла та, которая была утверждена только одними дворянскими депутатскими собраниями, но не обладала имениями. К третьему разряду отнесены шляхтичи, не утверждённые в дворянстве и без собственности.

Первый разряд освобождался от налогов и военной службы, для лиц второго - такое освобождение продолжалось до времени рассмотрения их дел Герольдией. Последняя категория шляхты была подвергнута немедленному налогообложению и выполнению воинской повинности. При этом депутатским собраниям западных губерний запрещалось выдавать новые удостоверения на дворянство без согласия Герольдии.

Учитывая злоупотребления чиновников местных администраций Правобережной Украины, попытки польской шляхт сохранить свой социальный статус любыми способами, влияние крупных польских землевладельцев на собрания шляхты, царское правительство усилило надзор за ведением документов, которые подтверждали права и привилегии шляхты. В конце 1833 г. были созданы особые комиссии для рассмотрения метрических и актовых книг. В их состав вошли чиновники Министерства внутренних дел, Министерства юстиции, Корпуса жандармов.

В ходе ревизии титулов уже в ноябре 1833 г. в трёх губерниях Правобережья было деклассировано более 70 тыс. (из 410-ти тыс.) человек польской шляхты. Лишь в Подольской губернии до конца 1833 г. в статус однодворцев и статус граждан было переведено соответственно 30259 і 762 человека ${ }^{6}$.

Такие шаги власти стали ударом по дворянским собраниям и вызвали протесты их руководителей, поскольку на тот момент только они могли свидетельствовать шляхетные права. В ходе процесса декласации шляхты дворянские собрания Правобережья постепенно утратили свои права и функции. Нужно отметить, что ещё с начала 1832 г. старые собрания шляхты - сеймики получили название дворянских собраний. Польские титулы изменились: маршалок - на титул предводитель дворянства, а хорунжий, пидсудок, пидкоморый были ликвидированы. Согласно указу от 12 октября 1835 г. право голоса имели лишь шляхтичи, удовлетворявшие ряд требований: которые могли подтвердить 10-летнюю службу в императорской администрации, наличие высшего образования или 6-летнее пребывание на какой-то шляхетской должности. В Волынской губернии в 1840 г. таких лиц

\footnotetext{
${ }^{6}$ Соловйова Т.М., Черепанов А.І. Київська губернія в першій половині ХІХ сm. : історико-правові , соціокультурні виміри. Переяслав-Хмельнищький, 2017. с.122.
} 
насчитывалось 1496 (в Киевской - 514, Подольской - 693). ${ }^{7}$ Польская шляхта протестовала против такого развития событий. Например, в мае 1832 г. предводитель подольского дворянства граф К. Пшездецький обратился к генерал-губернатору Левашову с просьбой похлопотать в столице империи о сохранении полномочий дворянских собраний, права которых были гарантированы грамотой Екатерини II. Подобные обращения были сделаны графом Г. Тишкевичем от имени киевской шляхты и Г. Маркевичем от волынской.

Однако это не дало положительного результата. С августа 1834 г. дворянские депутатские собрания Правобережья потеряли одну из главных своих функций - выдачу и регистрацию генеалогических доводов. С тех пор этот вопрос находился в ведении имперскогоправительства.

Подобные попытки провести ревизию деятельности дворянских собраний края делались и генерал-губернатором О. Гурьевым, который, однако, не смог продолжить на должном уровне дело, начатое Левашовым. Причиной увольнения этого генерал-губернатора стала его беспомощность и неумение подчинить воле администрации волынское дворянское собрание 1837 г.

Следующий киевский генерал-губернатор Д. Бибиков приложил большие усилия для реализации правительственного курса. За 15 лет его правления Юго-Западным краем (1838-1852 гг.) в регионе активно реализовывалась программа мероприятий по русификации края, активно внедрялись новые формы инкорпорации Правобережной Украины в российские государственные структуры, был определён ряд приоритетных мероприятий. Среди них: закончить ревизию дворянских дел, провести реорганизацию полиции и поставить её в подчинение местной власти. ${ }^{8}$

Д. Бибиков применял решительные меры, направленные на преодоление сепаратистских тенденций дворянских собраний. Генералгубернатору удалось узаконить свои требования относительно прав выборности дворянства. Для участия в выборах польской шляхты были определены условия - определённый стаж военной или государственной службы. ${ }^{9}$ Обратившись в столицу, в Комитет по делам Западных губерний (1831-1848), генерал-губернатор нашёл там поддержку. А уже 15 апреля 1840 г. Николай І именным указом ввёл новое положение для уездных судов.

\footnotetext{
${ }^{7}$ Грукач В., Ткаченко О. Інститут генерал-губернаторства у Правобережній Україні : правові засади та особливості функиіонування (1832-1914 рр.) ПереяславХмельницький, 2017. с.97.

${ }^{8}$ Шульгин В.Я. Юго-Западный край в последнее двадияатипятилетие (1838-1863)

K.1864. c.119.

${ }^{9}$ ПСЗРИ-2 : за 1845 г. СПб., 1846. № 18860.
} 
Теперь судей и дворянских заседателей, которые до недавнего времени избирались местным дворянством, начали назначаться российские чиновники. Введена как временная, эта мера обновлялась перед каждыми новыми выборами судей.

В годы правления Д. Бибикова процесс декласации шляхты набрал особых оборотов. По выражению Д. Бовуа в ход была запущена огромная машина для её «перемалывания». ${ }^{10}$ На предложение этого генерал-губернатора указом от 4 января 1840 г. учреждалась Центральная Ревизионная Комиссия (ЦРК) по рассмотрению дел дворянских депутатских собраний для правобережных губерний: Киевской, Волынской и Подольской, которая должна была закончить свою работу до января 1844 г. ${ }^{11}$ Созданная комиссия заменила три губернские и подчинялась непосредственно генерал-губернатору [96, №№ 13047, 13048]. ${ }^{12}$ При этом вводились ограничения для внесения шляхты в дворянские родовые книги. Последствия работы ЦРК сохранились в специальном фонде Центрального государственного исторического архива Украины в г. Киеве (фонд 481, оп. 1; 2), которые свидетельствуют о масштабной акции по ликвидации целого социального сословия Правобережья. ${ }^{13}$

Даная комиссия развернула огромную деятельность, пересматривая тысячи страниц документов, используя которые шляхтичи надеялись доказать своё дворянское происхождение.

Среди тех письменных доказательств, которые рассматривала ЦРК, известны следующие:

- юридическо-правовые: привилегии польских королей, свидетельства о принесении присяги Российской империи, свидетельства ревизионных палат, паспорта, решения о внесении в дворянские родословные книги, выводы и решения предыдущих ревизионных комиссий и Герольдии о шляхетском происхождении;

- свидетельства о родословной: метрики о крещении и погребении, добрачные соглашения, свидетельства о браке, выписки из метрических книг (в случае, если не было оригинала, родовые посемейные списки, расписки поколений, гербы тощо;

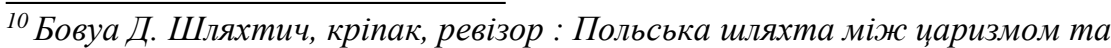
українськими масами (1831-1863). (Київ : ІНТЕЛ,1996) с.72..

${ }^{11}$ ПСЗРИ-2 : за 1840 г. СПб.,1841. № 13046.

${ }^{12}$ ПСЗРИ-2 : за 1840 г. СПб., 1841. № 13047; № 13048.

${ }^{13}$ Центральний держсвний історичний архів Украӥни ум. Києві (далі ЦДІАУ). ф. 481. on.1,2.
} 
- хозяйственно-правовые доказательства: купчие контракты, документы о введение в собственность поместий, доверенность на ведение дел, долговые расписки, протесты и решения по судовым искам (долги, побеги крепостных т.п.), дарственные записки, завещания, свидетельства на недвижимую и движимую собственность. ${ }^{14}$

Созданный ЦРК аппарат не мог подробно рассмотреть предоставленные документы, поскольку являл собою простой механизм с чётко отлаженной программой. Комиссия, руководствуясь рекомендациями Герольдии с недоверием относиться к предоставленным доказательствам, которая была завалена бумагами, отбрасывала или ставила под сомнение право на дворянство почти каждой семьи, которая не имела земельной собственности.

В 1845 г. возник вопрос о прекращении подачи доказательства дворянства и был предложен перевод шляхты в статус однодворцев или граждан. Отдельно составлялись списки тех, кто не смог предоставить доказательств, но имел право на их продолжение. Такие списки подавались губернскими дворянскими собраниями в Сенат только с подтверждением генерал-губернатора. Подтверждение генерал-губернатора требовалось и при подаче документов, по которым шляхте предоставлялось дворянство.

Во времена правления Д. Бибикова, в ходе привлечения польской шляхты к государственной и военной службе, вновь возник вопрос о соответствии польских и российских чинов, который рассматривался правительством ещё в начале XIX в. В 1820 г. военные польские чины были уравнены с российскими. Однако вскоре этот вопрос снова был пересмотрен и права польских чинов были ограничены. А после восстания 1830-1831 гг., когда многие шляхетские роды начали доказывать своё дворянское происхождение, вопрос о правах польских чинов стал особенно острым и постоянно находился в центре внимания.

В июле 1838 г. на заседании Сената Герольдии было поручено изучить все необходимые материалы для решения этого вопроса. За поручением Герольдии дворянские депутатские собрания западных губерний составили описания всех польских чинов и должностей, отправляя результаты своей работы губернаторам и в столицу империи. И только в феврале 1852 г., когда уже большинство польской шляхты было деклассированно и переведено в категорию податного населения, был законодательно определён перечень

\footnotetext{
${ }^{14}$ Лисенко С. Правобережна шляхта. Кінецьь ХVIII - перша половина XIX ст.: Списки иляхти Волинської, Київської та Подільської губерній, дворянські права якої перевірила Центральна ревізійна комісія. Біла Церква. 2002. с.243.
} 
бывших гражданских званий и должностей, которые существовали в Польше и могли послужить доводами для подтверждения дворянских прав.

Нужно отметить, что из бывших гражданских званий и должностей, которые существовали в Польше, доказательством шляхетства признавались такие :

- с государственных должностей: воеводы, самоготского старосты, каштелянов высшего и нижнего разрядов, обер-гофмаршала, надворного маршала, великого гетмана, польного гетмана, обер-канцлера, великого подскарбея, надворного подскарбея, коронного секретаря референдария (помощник канцлера), великого писаря хорунжого, надворного хорунжого, мечника, хранителя королевских драгоценностей, карного прокурора, помощника карного прокурора (вице-инстигатора), коронного войського, регента (правителя дел верхней та нижней Канцелярии), метриканта, секретаря, архивариуса, инстигатора, кассира и контролера комиссий: финансов, едукационной, военной и маршальской, депутатов Трибуналов, асессоров асессорских и референдарских судов; Литовських - войского, мерничего, граничного и коморника Великого княжества Литовського;

- из придворных должностей: великого пидкомория (обер-камергера), великого конюшего (обер-шталмейстера), подконюшего, ловчего, надворного ловчего, кухмистра, стольника, подчашего, крайчего, пидстолия, чешника и шамбеляна (камергера).

- из земских должностей: подкомория, старосты, судебного подвоеводы, городского старосты, городского судьи, городского писаря, уездного маршалка, хоружого, земского судьи, писаря, регента, стольника, подстольника, чешника, подчашия, ловчего, меченосца (мечника), конюшего, крайчего (крайчия), скарбника, обозного, стражника, мостовничего, строителя, лесничего, становничего, подконюшего, ключника, подключника, городского помостника, городничего, старшего и младшего трибуна, виленского трокского и самоготского цивунов, патрона и адвоката при Трибуналах, регента асессорских и референдарских судов, возничего у Литве, регента и вицерегента (земских и городских судов), ротмистра. ${ }^{15}$

После подавления восстания 1863-1864 гг. правительство отказалось от компромиссов с польской шляхтой Западного края, о чём свидетельствует распоряжение Сената от 23 сентября 1864 г., которое было предложено генерал-губернаторами. Речь шла о прекращении поисков шляхтой

${ }^{15}$ TsDIAU, f. 442. Kantseliariia kyivskoho, podilskoho i volynskoho heneral-hubernatora, op. 102, spr. 231. ark.8.ЦДІАУ. ф. 442. on. 102. сnр.231. ap.8. 
письменных доказательств шляхетских прав. Согласно закону, все шляхтичи, которые не состояли на государственной службе, не получили чинов и вовремя не подали документы на подтверждение дворянства, переводились в категорию податного населения. Правительство обязало генерал-губернаторов ЮгоЗападного и Северо-Западного краёв подготовить правила, которые бы сделали невозможным уклонение от этой акции. ${ }^{16}$

Таким образом, первые генерал-губернаторы определили политику центра к Правобережной Украине, контролировали социальные процессы на местах, инициировали законодательные и нормативные акты и механизмы их реализации, определяли практические мероприятия, направленные на интеграцию этого региона в состав империи. После подавления восстания 1830-1831 гг. польская шляхта в глазах российского правительства потеряла право на особое положение как в регионе, так и по всей империи. Потому генерал-губернаторы края были нацелены поощрять изменения, которые могли бы способствовать быстрейшему достижению задач правительства.

Таким образом, декласация многочисленной польской шляхты, которая проводилась имперской властью так системно и последовательно в течение трёх десятилетий, нанесла роковой удар по шляхетской солидарности. За период 1832-1850 гг. почти 340 тыс. шляхтичев, что не имели земли, были исключены из родовых дворянских книг и зачислены в разряд податного населения [204, с.112] ${ }^{17}$.

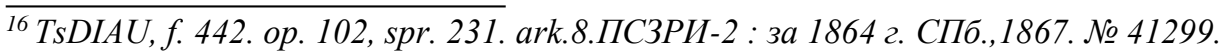

${ }^{17}$ Grukach V., Tkachenko O. Institute of General Governorship in ..., 99. ЦДІАУ. ф. 442. on. 102. cnp.231. ap.8.
} 